Film Take

\title{
One True Thing about Mothers and Feminism
}

\section{Linda Beail}

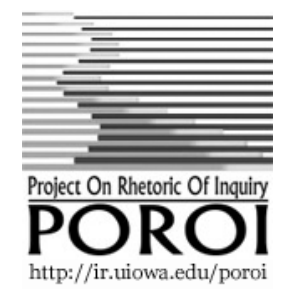

Poroi, 5, 1, September, 2008

1 In modern liberal societies such as the United States, "citizens" are presumed to possess certain defining characteristics: freedom, autonomy, the ability to act in their own interest and that of the larger public, plus the capacity to take responsibility for those actions. Powerful and enduring ideologies of motherhood prescribe an identity for women that is almost the opposite. The "good mother" is connected, nurturing, selfless: part of a dyad defined by dependency and self-sacrifice. Accounts of women's political identities and possibilities for exercising power must grapple with the dilemma that these opposing roles create for women.

2 Popular films help express political culture and construct it. They explore identities and ideologies for women to address the dynamics of motherhood dilemmas. Film representations of women can help us see how our society negotiates the overlapping or undercutting definitions of motherhood, citizenship, and personhood. Based on Anna Quindlen's novel, the 1998 movie of One True Thing recognizes such a dichotomy in the relationship between a traditionally "good mother," Kate, and her independent, career-minded daughter, Ellen. Especially in comparison to the novel, this film helps specify how we juxtapose and problematize these opposing identities. In the unsettled spaces between Ellen and her mother, and between the film and the novel, there is room for more subtle and sophisticated understandings of women's identities: not as mutually exclusive categories of citizens or persons versus mothers but as selves-in-relationship. This can let us value the individual subjectivity of women along with the connectivity we celebrate for mothers.

\section{Reason or Difference}

3 In modern cultures since the enlightenment, one of the challenges for feminist political theory has been how to justify women's 
claims to equality. The modern tendency has been to categorize realities into mutually exclusive dichotomies - such as mind versus body, reason versus emotion, public versus private, civilization or technology versus nature - and to value the first terms while discounting the second. Women have commonly been identified with the second, lesser terms. Seen as weaker and morally inferior, women have had to argue for full personhood, as opposed to traditions that have treated them as deficient or deformed by male standards for (truly) human being. Yet enlightenment ideas about humanity, individuality, and natural rights began to undermine western ideas about the inherent inferiority of women. Feminist thinkers such as J ohn Stuart Mill and Mary Wollstonecraft held that the moral and intellectual capacities of women might possibly be greater than previously suspected. Perhaps, the reasoning has gone, as liberal theory is pushed further in service of equality, the only way to know whether women (or blacks or other supposedly "inferior" people) are capable of participating in intellectual or public life is to allow them access and see how they perform.

4 One realm where women began to demand equality of rights is politics. The first wave of American feminism has been characterized by its most visible and successful struggle: winning access to the vote. Conventional accounts have the women's suffrage movement in the United States beginning in 1848 in Seneca Falls and concluding over 70 years later with the passage of the Nineteenth Amendment in 1920. During that time, many of suffragists based their arguments on liberal, enlightenment ideas about natural rights and the political equality of non-similar persons. Women's rights activists modeled the Seneca Falls Declaration of Rights and Sentiments on that foundational document of liberal enlightenment and democratic theory, J efferson's Declaration of Independence, and demanded to exercise their own inalienable rights. Following Wollstonecraft, they asserted that women - as humans - possess a God-given rationality that makes them equally fit for decision making. Reason, they argued, is not a gender-specific trait. This led women to work for access to educational institutions as well. As notions of citizenship expanded to include nearly all white males (not just property owners), then African-American males, feminists insisted that women too should be able to participate in politics. As persons endowed by their Creator with inherent natural, and not governmentally-granted, rights and reason, women too should be considered citizens with the right and responsibility to take part in 
politics.

5 Along with liberal, rights-based rhetoric, suffragists also developed a rhetoric of maternal ability and duty to justify the women's movement into direct political participation. An ideology of "republican motherhood" had helped create a role for women in politics as the educators of future (male) citizens in civic virtue, and this was familiar to eighteenth- and nineteenth-century Americans (Kerber 1980). It kept women in their traditional private, domestic, compassionate - place in modern dichotomies, yet it hinted at room for them within the new liberal-democratic paradigm for politics.

6 Suffragists drew on this understanding of women's proper role as virtuous mothers and moral exemplars to justify their move into the voting booth. They argued that women would be a muchneeded good influence on the corrupt and unsavory politics of city and state machines. The purity of the Victorian "angel in the house" could counteract the narrow self-interest and outright graft apparent in so much of American politics. Suffragists often carried brooms in their parades to symbolize the way their "natural" homemaking skills had prepared them to "clean up" politics.

7 Thus suffrage rhetoric was mixed. Some downplayed gender difference by asserting women's rights in terms of their (disembodied) personhood and rationality. Others emphasized women's femininity along with the domestic and maternal experiences that could make them uniquely valuable to the political process. This mixed message about women's identities and relations to politics led to many disagreements within the suffrage movement. Perhaps the most famous clash was between the more traditionally feminine NAWSA led by Carrie Chapman Catt and the more radical, hunger-striking National Women's Party headed by Alice Paul (Wheeler). But the diversity of tactics and messages within the movement allowed it to appeal on various grounds to a wide range of American women, helping it become a mass movement that was eventually successful in pressuring the political system to respond to its demands.

8 While perhaps strategically useful, these differing conceptions of gender identity can be theoretically problematic. The "difference versus equality" dilemma and related debates over essentialism became even more prominent in the second wave of American feminism. This has become apparent in political arenas, among others. Questions have arisen over what constitutes "women's" 
issues and whether it is important to elect women to political office. Do women govern "as women," or do they represent constituents in the same ways that as male representatives? Why? And what might it mean to legislate "as a woman" - especially when race, class, religious, or other differences among women create disagreement about what a "woman's" point of view might actually be?

9 Both strands of rhetoric about women's identity have been evident in the activism of the second wave. Such generalizations can be oversimplified, but it is fair to say overall that "liberal" feminists have continued in the enlightenment tradition of stressing that women are not inferior to men, particularly when it comes to rationality, intellectual ability, and moral responsibility. In downplaying women's "difference" from men, liberal feminists have been successful at dismantling many discriminatory laws that prohibited women from gaining access to jobs, education, sports teams, public accommodations, property ownership, and credit. They have demanded equal pay for equal work and broken through some professional glass ceilings.

10 At the same time, "cultural" or "difference" feminists have argued that it is a mistake for women to seek competition on a masculine playing field. What is really needed is a revaluing of women's traits such as nurturing, emotion, compassion, connection to nature, and attention to everyday tasks. They have rejected the enlightenment notion of disembodied reason as what makes us truly human, focusing instead on embodied and relational persons. They have argued for a "different voice" of women in moral reasoning (Gilligan 1982) and the value of "maternal thinking" in politics (Ruddick 1999; Elshtain 1981). In the legal arena, cultural and difference feminists have created new concepts like "sexual harassment" and "date rape" that depend on a specifically female point of view rather than the standard "reasonable (male) person."

11 Both understandings of women's identity have been politically important. Insisting that women are not some inferior sort of being but are persons, just as men are, has enabled women to gain access to greater power and resources. Acknowledging difference - particularly when it comes to issues of sexuality and reproduction - also has been important for women. It helps to create societies that recognize the lived experiences of all their members rather than basing their practices on norms that fit only half the population while unjustly ignoring or penalizing the other 
half. But for feminists, the underlying dilemma remains. To insist on personal equality is to take advantage of powerful rhetoric. Yet to buy into disembodied equality is to ignore realities of sex and gender difference that are still significant in our cultures and still speak in some persuasive ways to women as well as men. Gender has not (yet?) become an interesting but largely irrelevant characteristic, like eye color; gender carries real and often determinative social meanings.

12 On the other hand, positing any female "essence" ignores important differences between women. Worse, it can be used against women, to justify once again their exclusion from certain arenas like the pulpit, the Citadel, or the Oval Office. Feminist theorists have begun to argue that women need to reject the mutually exclusive dichotomy of "difference versus equality," just as they have rejected so many modern dichotomies harmful to women. In a postmodern mode, they attempt instead to find other frameworks that understand how gender identity is contextually and diversely constructed. These would allow for multiple identities or fragmented subjectivities that are performative and free but not misconceived as simply chosen. For example, the well-known Signs exchange in 1997 between Felski and Braidotti drives in such directions.

\section{Motherhood Matters}

13 Motherhood is an especially interesting site of contested meaning for women's identities. Pregnancy and childbirth are biological markers of sexual difference. As Sharon Hays points out in The Cultural Contradictions of Motherhood (1996), moreover, an ideology of "intensive motherhood" has evolved as a foil to our reifying the competitive pursuit of self-interest in public and professional settings. She argues that we have raised the societal standards of motherhood to unrealistic levels. Thus we hold individual mothers primarily responsible for child-rearing practices that are increasingly child-centered, expert-guided, emotionally absorbing, labor-intensive, and financially expensive. She writes that our cultural ambivalence about competition and self-interest have led to over-idealization of motherhood as the opposite. This has the consequence that working mothers expected to be ambitious and competitive in the workplace but nurturing and selfless at home - face impossible double-binds.

14 Patrice DiQuinzio echoes this judgment in the title of her book on The Impossibility of Motherhood (1999). Being a "mother" and a 
"person" are incompatible identities in current social and political contexts, dominated as they are by our ideology of individualism. She argues that individualism conceives human subjectivity as "a set of capacities, primarily reason, consciousness, or rational autonomy, which enable rational, independent self-determination and action" (p. 7). For these, the body is supposed to be merely instrumental. Thus this subjectivity is fundamentally disembodied. It is also coherent, stable, and singular. And it is the source of political action and entitlement.

15 This is in stark contrast to what DiQuinzio calls the ideology of "essential motherhood." That conflates motherhood with womanhood: making motherhood inevitable and natural for women. It requires women's "exclusive and selfless attention to and care of children based on women's psychological and emotional capacities for empathy, awareness of the needs of others, and self-sacrifice" (p. xiii). Personhood or subjectivity means a unified, self-interested, rational actor. But motherhood, beginning with the blurred boundaries of the pregnant body, neither stays wholly singular nor allows room to consider only oneself. As a result, motherhood and subjectivity are inherently at odds with one another in our current cultural conceptions. Yet by such a standard, if women are mothers, they are not "citizens." They are not autonomous persons who can exercise political judgement. Mothering becomes important for feminism because it encapsulates the "difference versus equality" dilemma underlying so many issues.

16 DiQuinzio rejects this dichotomy in favor of the "paradoxical politics of motherhood." These face the challenge of theorizing embodied subjectivity. Rather than seeing minds and bodies as opposites in competition for superiority, these maternal politics take seriously the ways in which minds and bodies constitute themselves mutually. They understand subjectivities as partial, fragmented, and sometimes contradictory. They recognize how subjectivities continually redefine or renegotiate themselves social relationships, some reciprocal and others not. In these ways, "maternal embodied subjectivity" represents not "a deviant or failed subjectivity, but a paradigmatically human subjectivity, [with] pregnancy as a crucially important instance of the embodied processes of subject constitution in which all subjects continually participate. ... [It] represents the mother-child relationship, in which a mutual, reciprocal, and ongoing constitution of subjectivity occurs, as a paradigmatically human relationship" (p. 245). This helps women by removing the false, forced choice 
between personhood (subjectivity, political agency, etc.) and being a mother. It highlights the value of women's experiences (and feminist principles) for all persons. Learning from postmodern criticisms of modern individualism, it creates a conception of subjectivity that is more likely to prove realistic and useful.

17 Yet an urgent question is how to get from philosophical contemplation of such paradigms of identity to widespread political and cultural transformation of them. After all, the power of both individualistic and maternal ideologies comes less from any conscious articulation than from their everyday domination of our cultural understandings and practices. We just "know" what it means to be a good citizen - or a good mother. How do we construct and transmit such identities?

18 One powerful way is through popular culture. As Annette Kuhn notes, "the ideological - a society's representations of itself within and for itself and the ways in which people live out and produce those representations - may be seen as a vital, pervasive and active element in the constitution of social structures and formations" (1994, p. 4). Representations in popular culture become, not mere entertainment, not something beneath political inquiry, but important sites of political action.

19 As scholars have emphasized for decades, film, television, and other popular media not only reflect aspects of social life but help create them. So feminists have reason to be concerned with representations of women's lives and identities in popular films. "If it is accepted that 'the cultural' may be subsumed within ideology," along with economic relations, says Kuhn, "then it becomes possible to argue that interventions within culture have some independent potential to transform sex/ gender systems. In other words, 'cultural struggle' becomes a political possibility" ( $p$. 4). Analyzing representations of motherhood in Hollywood films can become moments of feminist praxis. They can have important political consequences because film representations often have important practical implications for the everyday lives of American women. The understandings of motherhood and personhood presented on the silver screen are among the resources women use in constructing their own identities. Nothing less than political power and action are at stake.

\section{Women's Identities}

20 With these considerations in mind, let us turn to an analysis of 
motherhood and women's identities portrayed in the cinematic version of One True Thing. When the film was released in 1998, previews and advertisements marketed it as the latest in a long line of melodramas for women. In particular, they promoted it as a mother-daughter relationship film. Its predecessors in the genre would include Terms of Endearment (1983) and Steel Magnolias (1989). Like them, One True Thing has a plot that turns on the conflicted relationship between a mother and her daughter. In all three films, the relationship reaches a crisis occasioned by the terminal illness of one of the women. Such films feature familial complications that echo continuing tensions in social structures. Eventually their heart-wrenching events culminate in a tearjerking deathbed scene. Then the denouement dwells on how survivors learn and make good come from the loss.

21 Here the focus is on how One True Thing problematizes maternal subjectivity. It tries to complicate and question the modern archetype of the "good mother." In its representations of motherhood and daughterhood as resistance to the mother, it provides one possible glimpse of an embodied maternal subjectivity. Thus the film is a popular attempt to grope toward DiQuinzio's "paradoxical politics of motherhood." In the gaps and contradictions between the original novel and its screen translation, moreover, there are opportunities to see how this maternal subjectivity remains difficult to imagine. These contrasts help show where the choices between motherhood and personhood are still too mutually exclusive in our cultural and political lexicons.

22 Both the novel and the film begin by setting up a dichotomy familiar to most audiences: a contrast between the domestic, selfless, traditional wife and mother and the ambitious, independent, single career woman. The film demonstrates this in one of its earliest scenes, not present in the novel. The cosmopolitan daughter Ellen Gulden dashes out of her busy Manhattan office, shoves her way through a crowded subway platform, and boards a train for the "alternate universe" of the film. Her destination is the idyllic suburban home of her childhood, where she is headed for her father's surprise birthday party.

23 We have already learned in a voiceover that acquaintances have described Ellen as cold, insensitive, condescending, with ambition as her religion. The film demonstrates this visually with shots of her working late at night in a deserted office, mixing packets of 
Kava with Coca-Cola in her determination to stay awake and get ahead. Ellen herself admits, "I was ambitious. I still am. My father taught me to work hard at everything I do and I always have. ... I was never close to my mother growing up." Arriving at home for the party, her brother asks Ellen why she is not in costume, since the guests were to come dressed as their favorite literary characters. (The father is a literature professor.) An urban sophisticate clad all in black, Ellen replies, 'You know I can't do costumes. It's just so ...." "Human?" her brother supplies. " Mom!" Ellen retorts contemptuously.

24 The contrast between mother and daughter becomes even sharper when Kate Gulden emerges from the house. She calls out, "Yoohoo! There she is, there's my girl," while embracing the reluctant Ellen in an exuberant hug. Kate is in full costume, wearing a frilly gingham dress, yarn pigtails, and ruby slippers as Dorothy from The Wizard of Oz. The outfit makes her look girlish and unsophisticated; and when she asks Ellen to guess her character, the daughter begins to sing, "If I only had a brain ...." This song from the movie musical is the gist of Ellen's assessment of her mother. She surveys the birthday feast spread out on many counters in the huge, well-tended kitchen and remarks dryly, "This must have taken you days." Her mother hesitates then replies, "Oh. Well, thank you," even though Ellen's tone of voice was more amazed (that anyone would waste so much time cooking) than complimentary.

25 When a guest asks Ellen her character for the party, she saucily replies, "Lizzie Borden - took an ax, gave her mother forty whacks." In the kitchen, she picks up a knife and starts slicing a loaf of bread, but she is obviously out of her element. Her mother watches her with distress, first diplomatically handing her a bread knife (to replace the large paring knife she's inadvertently hacking away at the loaf with), then suggesting that she "saw it, back and forth" as Ellen continues to mangle the loaf. Ellen glares at her but then slices her finger, and Kate offers a home remedy for the bleeding that involves a brown paper bag. When Ellen ducks to escape her mother's hug and attention, she clumsily knocks a plate to the floor. Ellen could not be more out of place, but Kate simply tells her to save the shattered pieces for one of her craft projects. When Kate sails out of the kitchen to answer the door, calling "Hello! There's no place like home!" (alluding to her Dorothy costume), Ellen mutters a heartfelt, "Thank God.”

26 Though Ellen clearly does not want to identify with her mother or 
her mother's domestic world, she idolizes her father. When her mother compliments her on her latest magazine piece, she dismisses it as "not a big deal." What she really wants to know is, "Do you think Dad read it?" Her mother's praise is discounted, but when she finally gets her father alone later in the evening, his approval of her work is all that she craves. She is crushed by his criticism that her writing is "overemotional" and needs to be "more muscular." It is the opinion of the father that is powerful and valuable here. When George Gulden comes through the door of the house, everyone yells "Surprise!" Kate hangs on his arm, clapping and giggling. In contrast, Ellen stares at him adoringly from across the room, remembering a similar scene from her girlhood when one of his classes gave him a standing ovation; she clearly holds him in that same kind of heroic awe. Both father and daughter consider themselves highly intellectual, sneering at the costumed party guests who "seem to get all their literature from Disney." From their conversation, we learn that he was also a magazine writer when he was in his twenties and that he has won a National Book Award. His daughter's choice of career and her attitudes indicate that she aspires to be like him - and not at all like her mother.

27 Ellen loves the public, professional world of her career - her father's world. But it is in the opposite world of home - of maternal domesticity - that she comes to care for her mother, diagnosed with cancer. Her father demands that she quit her job in the city to tend her mother, and resentfully Ellen complies. When she wonders why he cannot take a sabbatical or hire a nurse to care for Kate, he asserts the demands on his career but dismisses the impact that leaving New York will have on Ellen's. 'You can freelance from here. . . . your mother didn't get a nurse when you had the chicken pox! Your mother needs you, Ellen. J esus Christ, you've got a Harvard education, but where is your heart?" Ellen is about to enter the classic double-bind, the expectation of both individual subjectivity and maternal caretaking. Her father has trained her to excel academically, but now he expects her to be nurture more or less maternally.

28 The next shots show Ellen resigning from her job, subletting her apartment, and getting on the train to leave the city. She yields to her father's wishes; but as she stands for a long time outside the large, storybook house of her youth, silently gathering the strength to go inside, we sense her reluctance. She has not come home because she wants to, but because she is bending to her father's will. Despite her ambition and independence, she lacks the ability 
to separate from him and make her own, adult choices. Ellen may resist being her mother's daughter, with its resonance for Nancy Chodorow's "reproduction of mothering" cycle for women's identities (1978); but she is still her father's. This implies that simply rejecting domesticity or emotion, the stereotypically "feminine," in favor of individualist and masculinist values of rationality, competition, and career success does not dissolve the double bind for women's identities. The dilemma of subjectivity is too complicated to dispel it by simply choosing to emulate the father rather than the mother.

29 Ellen's anger and disgust at taking over her mother's role in keeping the household running for her father reinforces the contrasts between Ellen and Kate. Shortly after Ellen returns, her father asks her to write the forward to his latest book. She is flattered and immediately agrees; but she is confused and deflated when, along with the manuscript, he also hands her his shirts to be laundered and mended, as if these are both tasks for which she is equally suited. She complains repeatedly about her father's lack of participation in any of the household chores. After cooking Thanksgiving dinner for the entire family, for which she gets little appreciation, she asks her mother, "How do you do this? All day, every day in this house and no one notices? Doesn't that drive you crazy?" Kate looks genuinely surprised and replies, "This is my family, Ellie. These are the people I love. Maybe it's time for you to start thinking about going back to New York, to your writing, all the things that you like to do."

30 Ellen does not go back to the city, however, as her mother's health fails more rapidly. During the illness, we see Ellen begin to reevaluate her mother's life. Her initial disdain of Kate's culinary skills becomes admiration after she volunteers to cook lunch for the "Minnies," the women's group of community volunteers to which her mother belongs: "Show me how. It can't be that hard." The bright, shining kitchen becomes a chaotic mess of eggshells and spilled flour. Every pot and pan is in use. The cake comes out lopsided, the chicken burned; and the scene culminates in a spectacular grease fire. Ellen begins to have some appreciation for her mother's talents and skills. Much later we see her easily cooking the Thanksgiving turkey and even reorganizing the kitchen while baking her brother a pie: quite a change from her initial ineptitude and contempt.

31 Ellen begins to see that there is more to her mother than the simple J une Cleaver image that meets the eye. Frustrated that 
they have wasted an entire afternoon driving around aimlessly and singing along to the radio with one of her mother's friends, she discovers that Kate has been quite purposeful. The friend is suffering from severe depression, and it has been Kate's turn to get her out of the house and cheer her up. Ellen reluctantly takes part in the Minnies Halloween carnival, only to discover that she actually enjoys it. At first, she spends all her free time trying to write a story for her former magazine; but we later see her working on her mother's craft projects instead. At one point, an exhausted Ellen tells her visiting boyfriend, J ordan, "I am just tired, very tired. Being my mother is very tiring." Having not seen Ellen since she left New York, still the hard-driving and scornful career woman, he replies, "Come on, there is nobody more different from their mother than you." The change in Ellen is obvious when, instead of agreeing gratefully, she screams angrily back, "That is the stupidest thing that you have ever said!"

32 Unfortunately the film simplifies this transition between emulating her father's values to her mother's, making it a simple switch of loyalties. Plotwise this occurs when Ellen learns of her father's marital infidelities. Suddenly the idol has feet of clay. She begins to sympathize more with her mother and to suspect her father's motives, going so far as to accuse him of not encouraging her mother to seek treatment earlier because he didn't want his life disrupted. The limits of his genius appear in his writer's block, his recourse to alcohol, and his tiresome repetition of the same writing anecdotes. A few times, the film resists painting him as the villain, showing moments of true passion and affection between George and Kate. Yet too often, it devolves into presenting another oversimplified dichotomy: cold, heartless masculinity (George) versus mindless, nurturing maternity (Kate). Then the only question is which choice is right? By the film's logic, the maternal, selfless values of Kate seem superior. Is this a defeat for feminist empowerment, for women's attempt to claim subjectivity?

33 It is true that Kate has made sacrifices. She, too, knows about her husband's failings. After Ellen finds out about her father's affairs and becomes increasingly hostile toward him, her mother confronts her about her rage:

There is nothing you know about your father that I don't know, too - and understand better. You make concessions when you're married a long time that you don't believe you'll ever make when you're beginning. 
... you look at your husband, and he's not the person you used to think he was, but he's your life. The house and the children and so much of what you do are built around him and your life, too, your history. If you take him out, it's like cutting his face out of all the pictures: there's a big hole, and it's ugly. It would ruin everything. It's more than love, it's more important than love. ... It's so much easier to be happy, to learn to love what you have - and you have so much, my love - instead of always yearning for what you're missing or what you imagine you're missing. It's so much more peaceful.

Kate's compromises are not made blindly or unthinkingly, and Ellen realizes that she has underestimated her mother's insight and strength. As Quindlen has Ellen elaborate in the novel, "I'd taken a laundry list of all the things she'd done and, more important to me, all the things she'd never done, and turned them into my mother, when they were no more my mother than his lectures on the women of Dickens were my father. ... Our parents are never people to us, never" (1994, p. 171).

34 It is in recognizing this subjectivity of each of her parents, but especially of her mother, that Ellen begins to grow up and claim her own. She realizes that she has seen her mother in the way that DiQuinzio's ideology of "essential motherhood" encourages our culture to view mothers: as objects, existing instrumentally to nurture, support, and selflessly sacrifice themselves for another, the constant background against which another's subjectivity can develop. 'We'd made her simpler all her life, simpler than her real self. We'd made her what we needed her to be. We'd made her ours, our one true thing" (p. 276).

35 An inherent aspect of subjectivity is its complexity: that it can be comprehended only in part by another. In the film, this ultimate unknowability of another person is communicated via the mystery surrounding Kate's death. An autopsy reveals that she has died of an overdose of morphine. As her cancer became more debilitating and she became more helpless, she asked both her husband and her daughter to help her end her own life. We even see Ellen crushing up the pills, considering it, then sweeping them into the trash; and we can appreciate the irony of her no longer having any desire to get rid of her mother, but wanting to hang on to their relationship for as long as possible. 
36 Later Ellen finds the empty pill bottle in the garbage and suspects that her father has fed them to Kate. But in the film's final scene, George finds Ellen planting bulbs at her mother's gravesite. He tells her how much he admires her courage in helping Kate take her own life. Ellen is stunned. Apparently Kate herself somehow had the strength to do what neither of George nor Ellen could. This shocking discovery causes Ellen once more to re-evaluate her understanding of who her mother was. Yet in the film, it is George, not Ellen, who gives the "one true thing" speech. Coming from the wayward but repentant husband, it sounds more like a tribute to the saintly wife and mother, affirming her identity as the touchstone of the family, than a recognition of the unplumbed depths of her subjectivity. The film's ending seems in this respect almost to subvert the novel's meaning, by reifying Kate as toogood-to-be-true, the "one true thing," rather than as a complex, flawed, valuable person.

37 The film also undermines the quest for maternal subjectivity in another scene where it differs from the novel. After Ellen returns home, her mother suggests that they have a book club, and they choose three novels to read together. The first is J ane Austen's Pride and Prejudice (1987). In the film, the two discuss the book while having a picnic in the park, and the visual contrast between Ellen and Kate is as stark as the character contrast that they discuss between Austen's Elizabeth and J ane Bennett. Ellen is dressed in her usual black, including a leather jacket, and seriouslooking glasses with dark rims. Kate is wearing a flowered blouse and dark red, embroidered sweater, while her blond hair is prettily curled: the epitome of femininity. Kate objects to the way that Austen "makes the sweet and domestic" sister play "second fiddle to Elizabeth, the outspoken and smart one." As Ellen keeps trying to interrupt, unsuccessfully attempting an edgewise word, Kate goes on, "There's another book that does it too. Little Women. Yes, the writer sister, she puts her in opposition to the one who has babies - Meg."

38 At this point, the film cuts abruptly to another setting. But in the novel, this scene is much longer and involves a real exchange between mother and daughter. Ellen learns that her mother is more educated than she had suspected, familiar with many classics of literature. Kate insists that "women writers of all people should know better than to pigeonhole women, put them in little groups, the smart one, the sweet one" - making it clear that her objection is not merely to the valuing of the "smart" one over the "sweet" one, but to the dichotomization itself (Quindlen 1994, p. 42). 
When Ellen says that J ane and Elizabeth are perhaps mere prototypes of women, equal in their admiration for one another, Kate disagrees: 'No, they're real enough, both of them, J ane and Elizabeth. J ane admires Elizabeth, and Elizabeth admires herself" (p. 42). Later, after Kate's death, Ellen thinks, my father "did what so many men do: he divided women into groups ... the woman of the mind and the one of the heart. Elizabeth and J ane Bennett. I had the misfortune to be designated the heartless one, my mother the mindless one. It was a disservice to us both but, on balance, I think she got the better deal" (p. 281).

39 The novel insists that women have minds and hearts. To make women choose between reason and emotion, private and public, selfhood and motherhood is a destructive mistake. The character of Kate, in the film but even more in the novel, demonstrates what a connected selfhood, an embodied maternal subjectivity, might be. She is not completely passive or dependent; she makes deliberate choices about when and how to assert herself, and when not.

40 Throughout the film, we see Kate making the choice to smooth over conflict in the family by gently changing the subject or offering some cheery observance unrelated to the issue at hand. During Thanksgiving dinner, for example, the mood grows tense when George is offended by another writer's comments about his novel. Kate defuses the situation by looking around the table at the feast Ellen has prepared (but her father not even acknowledged let alone complimented) and remarking, "This all looks wonderful, dear. Could you pass the mashed potatoes?" Initially Ellen would have been frustrated or dismissive of her mother's tactic. She would have viewed it as an inability to hold her own in an argument, debate the logic of different positions, or, most importantly, triumph over another person in a battle of wits. It takes her most of the film to realize that her mother's strategy may have indicated a position of strength, not weakness.

41 The film also shows Kate's maternal power - and her struggle with its loss and limits - as her health begins to seriously deteriorate. One afternoon, after Kate has been forced into a wheelchair most of the time, she is in the kitchen to direct Ellen in baking a pie. As Kate tries to maneuver around the kitchen, she grows increasingly frustrated from her inability to reach the oven or do any baking tasks she so recently took for granted. When she tries to tell Ellen where to find a pie plate, only to have Ellen reply that she has moved it in her own reorganization of the kitchen, Kate angrily 
grabs the plate and smashes it onto the floor. She wheels out of the kitchen sobbing, furious at how her body is betraying her and changing her life. She fumes, "It's my kitchen. I'm still the mother. I'm still the mother here." Being the mother has been for Kate a position of action, power, and freedom - as well as compromise, deferral, and accommodation.

42 Kate's intelligence, wisdom, and fierce strength - even the courage and autonomy to decide when her life would end - do not come at the cost of surrendering her compassion, warmth, and domesticity. All these intertwine. And Ellen, who begins by valuing the life of the mind as the be-all and end-all of existence, shifts allegiance somewhat as she spends more time with her mother. During one argument, her father snarls, "Have you lost your mind?" And she shouts back defiantly, "Maybe!" By this time, for her, that is no longer an utter defeat.

43 In the end, Ellen refuses to choose just one side of the dichotomy: the young woman who plants bulbs and smells "the lilacs under the soil" just as her mother did is the same young woman who returns to New York and resumes a high-powered career in journalism. She forgives her father his failings, but no longer romanticizes him. She claims her own subjectivity, but not on individualistic terms: she is a person for whom both the head and the heart are necessary and for whom both knowledge and love have been costly.

\section{What Counts}

44 Theorizing mother-daughter relationships may be important for feminism in a larger, metaphorical sense. The second wave of feminism often used the language of "sisterhood," but explicitly rejected "living our mothers' lives." Second-wave feminists imagined these to be the lives of quiet desperation and oppression evoked by Betty Friedan in The Feminine Mystique (1964). As second-wave theorizing flourished during the 1970s and '80s, feminists celebrated the ability to make choices and access opportunities unavailable to their mothers' generation. But as time has continued to pass, many of these same feminists have had children of their own. They are now mothers as well as rebellious daughters or powerful sisters. They have begun to seek ways to define the movement do not simply react against the previous generation of women, but create continuity and extend possibilities to their daughters. 
45 The need for women is to make sense of their own maternal identities in terms of their feminist beliefs. Even in public spheres, as opposed to the directly familial, women have faced this dilemma. In corporations and academia, older and younger women struggle with mentoring relationships and what feminism can mean across generations. What do we owe to one another? Are we simply in competition with one another to see who can achieve the most? Has the third wave of feminism been developing in contrast or even opposition to the agenda of the second wave?

46 Feminists have been addressing these issues. Generations: Academic Feminists in Dialogue (Looser 1997) is an early collection of essays that confront such questions. Diane Elam writes there that "the development of generational conflict, of disrespectful daughters and oppressive mothers, is not a wholly new phenomenon. ... What is perhaps new is how crucial the question of power within feminism has become" (p. 67). In the same book, Rebecca Dakin Quinn insists that we need to go beyond "simply killing our mothers and committing violence against our sisters in the name of institutional recognition, advancement, and power" (p. 177). She argues that feminism has been successful in criticizing patriarchal oppression but has gotten stuck somewhere between a utopian vision of female solidarity and fragmented paralysis due to the differences between women. Perhaps this revisits the "difference versus equality" dilemma? "Competition, compartmentalization, and commodification appear to have carried the day, for want of an alternative model of doing business. Mothers and daughters stand divided: how long until we are conquered?" (p. 177). It is simplistic and short-sighted to treat mothers as traditional, old-fashioned, and limited to the private sphere while urging daughters into the public sphere of work and masculine values. That preserves a mistaken dichotomy.

47 The opening shots of One True Thing express this choice neatly. In a black-and-white flashback to her childhood, Ellen remembers a car trip with her family. At one point, this serious little girl announces, "I have to go to the bathroom." Her father looks annoyed and snaps, "Can't you hold it?" Ellen, not wanting to displease him, looks down at the floor then crosses her legs and vows, "Yes, I can. . . . I'll practice 'mind over matter."' Her father, the epitome of cold logic and disembodied rationality, says, "Atta girl." Her mother, knitting in the front seat, seems to doubt the feasibility of this plan, murmuring, "Mmmmm, I don't know ...." As if to distract the little girl and somehow make this denial of a 
physical need more bearable, she looks out the window and exclaims, "Look at the baby cows, Ellie!" From the back seat, Ellen remarks primly, "I'm reading, Mom. And baby cows are calves."

48 Later in the film, after her relationships to father and mother have changed, Ellen remembers this scene, including her mother's quiet reply: "That's right, Ellie. Baby cows are calves." The first memory highlights how she identifies with her cerebral and demanding father. It also suggests her unquestioning acceptance of "mind over matter," valuing mind over body, and her father's reason over her mother's emotion. At a pivotal moment in the film, the second flashback offers a different message.

49 During the whole time she has been caring for her mother, Ellen has been working on a story about a Senator involved in a scandal. She calls sources and pursues interviews, believing that this story can somehow salvage the journalism career she has left behind. Eventually the disgraced Senator gives a press conference, but Ellen cannot get back to New York City in time to cover it. Frustrated but determined, she waits outside his hotel until he emerges, then pretends to be an old college classmate who recognizes him and strikes up a friendly conversation. Ellen lies, telling him she needs a ride to the airport so she can get home for her daughter's birthday party, and he kindly offers to share his limousine.

50 (This is not the first time she has deceived and played on others' emotions to get information for the story. Earlier we see her phoning a hospital to say that she is a close friend of the Senator in order to learn when he will be released from drug rehabilitation. It is telling that, when her mother overhears this conversation, Kate shows immediate concern and wants to know which of Ellen's friends is in trouble. Ellen simply rolls her eyes, puts one hand over the mouthpiece, and answers, "It's kind of a work thing, Mom." In honest confusion, Kate replies, "Oh. I thought you said it was a friend.")

51 Ellen jumps at the chance to get a scoop from the unwitting Senator, and we see her eagerly lapping up quotes and encouraging his confidences as they ride through Manhattan. When he muses, "I don't know what happened. . . you try and you try to get ahead, and then -" Ellen nods understandingly and murmurs, "You just - lose yourself." He continues, "You wake up, and your life is a disaster. I just hope I can make it up to my wife and kids. That's all that counts. All that counts." Ellen agrees, 
“You're right. They're the ones who love you. That's what counts."

52 Suddenly the obsequious nods stop, and she falls silent. Conflicting emotions flash across her face. She swallows hard and seems to realize that perhaps she actually believes what she has just said. Could it be true that she has in some way "lost herself" instead of making a success of her life? Could it be that "what counts" is nurturing and protecting relationships with "the ones who love you?" Could it be that emotional connection can be even more valuable than ambition, career success, publishing a novel, or always being "right" about the facts?

53 That is when the camera cuts from Ellen's face inside the dark car to the black-and-white scene which opened the film. As in the present, Ellen is riding in the back seat of a car. In this second remembering, she sees her mother more fully, not just in peripheral vision. In tight close-up, we see along with Ellen the pearl stud nestled in her mother's ear lobe and the blonde curls flipped up along the nape of her neck: the epitome of 1950s feminine iconography. The camera cuts to Kate's hands, busily knitting what looks like a baby's cap or a child's sweater. She is not reading, like Ellen or George, who reads passages aloud from the New York Times while he drives. She isn't drilling the children on some bit of knowledge, like their father. She isn't arguing with them or correcting them about a fact, as Ellen corrects her mother about the baby cows. Rather than thinking, talking, or engaging in some cerebral activity, Kate is doing. She is silently but industriously creating something useful, something beautiful, something warm. She is, as always, trying to keep the family knit together, close and in harmony rather than conflict.

54 As Ellen re-assesses this memory, she seems to recognize her mother's effort to distract her as the insightful and compassionate gesture it was, instead of some naïve delight at spotting the cows. She is able to notice, and focus on, her mother's ultra-femininity without dismissing it as totally useless or lacking value. She is able to question, suddenly, her assumption that the activity of the mind is always superior to the needs of the body and the workings of the heart. Kate knew what baby cows were called; but she did not need to assert her intellectual standing. Instead she could affirm her daughter's precocious answer with a smile then add a rueful nod. Perhaps she wondered if Ellen would ever take her nose out of her book to look at, and love, the world around her. Perhaps she sighed because she hoped that Ellen's brilliance would not keep her from wanting always to be right rather than sometimes happy 
or supportive.

55 It is important to notice that Kate did not discourage or dismiss Ellen's intellect in this scene. She accepted and encouraged it. But her actions indicated that she refused to live or evaluate life on the terms that George and later Ellen accepted as valid: mind over body, reason over emotion, ambition over contentment, public over private, winning over caring. As Anna Quindlen writes in the novel, "We had so misunderstood her, this woman who had made us who we were while we barely noticed it. . . . while I would never be my mother nor have her life, the lesson she had left me was that is was possible to love and care for a man and still have at your core a strength so great you never even needed to put it on display" (1994, pp. 285 and 288).

56 George is famous within the family for reminding them that "less is more," a saying that reflects his philosophy of writing but also his emotional distance. Kate instead tells Ellen, “I don't agree. To me, more is more." This philosophy of abundance - from the physical luxuriance of chintz and cushions and cinnamon toast at every turn to the more ephemeral overflow of Kate's laughter, generosity to friends and neighbors, and love for her family - begins to gain credibility for Ellen. As she ends up saying at her mother's funeral, "I never knew I could miss anyone so much" (italics added).

57 This is a turning point for Ellen. Her perspectives have changed for her parents and her own life. We know this because the next scene has Ellen call her editor and tell him that she never got to talk to the senator at all. Clearly her "win at all costs" mentality, in which getting the story was a game of wits she was ruthlessly determined to win, with no thought for ethics or harms, has begun to shift. She does not abandon her ambition or intellect, but she has come to respect her mother's priorities. This means revaluing her own relationships, feelings, even knowledge.

58 The epilogue to the novel indicates this even more strongly than does the film. In the film, Ellen gone back to journalism - albeit as a softer "feature writer" for The Village Voice. In the novel, she has switched careers completely to become an adolescent psychiatrist. This new vocation seems to fuse her father's ambition and intellect, so necessary for medical school, with the values she has learned from her mother: compassion, the ability to listen, respect for others, and humility in the face of their subjectivity.

59 One True Thing highlights the possibility for women to escape the 
double bind of equality versus difference, masculine individualism versus feminine essentialism. It does so at one of our most problematic sites: motherhood. It suggests some of the ways that women can refuse to base their identities on cultural dichotomies, even as it shows the difficulties for such resistance. It demonstrates how subjectivity is discursive, continually being reconstituted in relationships, and how it is never completely coherent or knowable by another. In the end, it suggests, we are each a mystery. By illuminating some of the complexity and mystery of this one mother and her daughter, One True Thing offers a glimpse of the possibilities of maternal subjectivity.

(C) Linda Beail, 2005.

\section{References}

Austen, Jane. 1987. Pride and Prejudice, Harold Bloom, ed. New York: Chelsea House.

Chodorow, Nancy. 1978. The Reproduction of Mothering: Psychoanalysis and the Sociology of Gender. Berkeley: University of California Press.

DiQuinzio, Patrice. 1999. The Impossibility of Motherhood. New York: Routledge.

Elam, Diane. 1997. "Sisters are Doing it to Themselves." Generations: Academic Feminists in Dialogue, Devoney Looser and E. Ann Kaplan, eds. Minneapolis: University of Minnesota Press.

Elshtain, J ean Bethke. 1981. Public Man, Private Woman. Princeton, NJ : Princeton University Press.

Felski, Rita. 1997. "The Doxa of Difference." Signs, 23, 1, Autumn 1997, pp. 1-40 .

Friedan, Betty. 1964. The Feminine Mystique. New York: Dell.

Gilligan, Carol. 1982. In a Different Voice: Psychological Theory and Women's Development. Cambridge, MA: Harvard University Press.

Hays, Sharon. 1996. The Cultural Contradictions of Motherhood. New Haven: Yale University Press. 
Kerber, Linda K. 1980. Women of the Republic. Chapel Hill: University of North Carolina Press.

Kuhn, Annette. 1994. Women's Pictures: Feminism and Cinema. London: Verso, 2d edition.

Looser, Devoney, and E. Ann Kaplan, eds. 1997. Generations: Academic Feminists in Dialogue. Minneapolis: University of Minnesota Press.

Mill, J ohn Stuart. 1998. The Subjection of Women. Indianapolis: Hackett Publishing Company, 1st edition, 1869.

Quindlen, Anna. 1994. One True Thing. New York: Random House.

Quinn, Rebecca Dakin. 1997. "An Open Letter to Institutional Mothers." Generations: Academic Feminists in Dialogue, Devoney Looser and E. Ann Kaplan, eds. Minneapolis: University of Minnesota Press.

Ruddick, Sara. 1999. Mother Troubles: Rethinking Contemporary Maternal Dilemmas. Boston: Beacon Press.

Wheeler, Marjorie Spruill. 1995. One Woman, One Vote. New Sage Press.

Wollstonecraft, Mary. 1988. A Vindication of the Rights of Woman, Carol H. Poston, ed. New York: Norton, 1st edition, 1792. 